\title{
Dorota Kubacka-Jasiecka
}

Uniwersytet Jagielloński, Instytut Psychologii Stosowanej

\section{Wzór zachowania typu C Rozważania i badania nad rozwojowymi uwarunkowaniami oraz korelatami WZC}

\section{Osobowość i wzór zachowania C}

Typ osobowości C, później wzór zachowania C (WZC), został po raz pierwszy wprowadzony przez T. Morrisa i S. Greera w 1980 r. (M orris i in., 1981; Temoshok, 1987) jako predysponujący do choroby nowotworowej (cancer-prone personality) czynnik ryzyka choroby somatycznej. Ryzyko dotyczy osób zahamowanych emocjonalnie, obciążonych sytuacjami stresowymi i krytycznymi.

L. T e m o s h o k (1987) przedstawił specyficzny styl radzenia sobie ze stresem, stanowiący konstelację poznawczych, emocjonalnych i behawioralnych tendencji, opozycyjny wobec wzoru zachowania A. Charakteryzujące się wzorem zachowania $\mathrm{C}$ osoby opisywano jako kooperatywne, spokojne, nieasertywne, ukrywające negatywne emocje, szczególnie gniew, uległe wobec zewnętrznych autorytetów. H. J. E y s e n ck (1994) podkreślał predyspozycje do uczuć bezradności, beznadziejności i depresji. Typ $\mathrm{C}$ stanowi $\mathrm{w}$ pewnym sensie przeciwieństwo wzoru zachowania A - wrogiego, funkcjonującego $\mathrm{w}$ dużym napięciu i kontrolującego. Uważa się, że typ A oraz jego przeciwieństwo - typ B i C - tworzą kontinuum (M a t the w s i in., 1996-1998; M ir ski, 1995, 1998).

Charakterystykę osobowości i wzoru zachowania $\mathrm{C}$ można przedstawić w formie trzech zespołów właściwości:

1. Silne, negatywne emocje wobec zagrożenia w sytuacji stresu:

- lęk, depresja, bezradność, przygnębienie,

- thumienie emocji i nadmierna kontrola, zwłaszcza gniewu,

- niskie kompetencje radzenia sobie ze stresem.

2. Zależność emocjonalna od osób znaczących:

- lęk przed odrzuceniem i porzuceniem emocjonalnym, dynamika ambiwalencji w związkach (ukryta, stłumiona złość i agresja),

- konformizm, uległość, poświęcanie się innym z pominięciem własnych potrzeb, niedostatek samoopiekuńczej funkcji Ja, „fasada dobroci”. 
3. Brak silnej więzi z życiem i problemy wokół Ja, słaba motywacja, niewielka siła życiowa („,biofilia”):

- osoby depresyjne, pesymistyczne, bezradne, samooskarżające z poczuciem winy,

- małe poczucie własnej wartości, niska samoakceptacja i integracja osobowości,

- niedostatek troski o siebie i samoopiekuńczych funkcji Ja.

Wzór zachowania C stanowi konstelację poznawczych, emocjonalnych i behawioralnych komponent funkcjonowania psychospołecznego, przyczyniających się do obniżenia odporności immunologicznej. Osoby ze wzorem zachowania typu $\mathrm{C}$ przedstawiane są jako: kooperatywne, spokojne, cierpliwe, nieasertywne, ukrywające, thumiące czy wypierające negatywne emocje (szczególnie gniew), uległe wobec zewnętrznych autorytetów (Dolińska-Zygmunt, 2001; Zakrzewska, 1989).

Zarówno osobowość typu C, jak i WZC nie zyskały takiego uznania i popularności, jak wzór osobowości A wiązany z chorobami serca - chorobą wieńcową i zawałami serca. Kontrowersje dotyczą zróżnicowanej terminologii oraz statusu przedstawianych charakterystyk oraz metodologicznych aspektów badań prowadzonych najczęściej na silnie zaznaczonym wzorze $\mathrm{C}$ oraz klinicznych grupach somatycznie chorych. Nie do końca wiadomo, czy mamy do czynienia ze:

- szczególną struktura, względnie stałym typem osobowości lub poszczególnymi względnie niezależnymi wymiarami osobowości,

- wzorem zachowania - szczególnym typem regulowania relacji z otoczeniem w dążeniu do adaptacji,

- sposobami radzenia sobie z presją otaczającego jednostkę środowiska,

- sposobami zmagania się ze stresem choroby somatycznej z przewagą negatywnych emocji i obronnego thumienia oraz wypierania nieakceptowanych przeżyć (np. Schwartz, za: J u c z y ń s k i, 2002).

Charakterystyki osobowości typu C, opisywane początkowo jako predysponujące do rozwoju chorób onkologicznych, zaczęto z czasem rozpatrywać w szerszym kontekście jako czynniki ryzyka psychosomatycznego predysponujące także do rozwoju innych chorób somatycznych: reumatoidalnego zapalenia stawów, choroby wrzodowej żołądka i dwunastnicy, a nawet osteoporozy (Matthews i in., 1996-1998; Kubacka-Jasiecka, Wysocka-Plec zyk, 1998; Kubacka-J a s i c ck a, 2006).

Teoretyczne rozważania $\mathrm{w}$ niewielkim stopniu są popierane wynikami badań empirycznych. Należy wspomnieć badania G. Matthews wraz z zespołem (1996-1998). Badacze opracowali za pomocą złożonej analizy czynnikowej typ „osobowości psychosomatycznej”, predysponującej do schorzeń psychosomatycznych. Za najważniejsze czynniki ryzyka psychosomatycznego autorzy uznali: 
- emocjonalne niezrównoważenie,

- cechy wzoru zachowania typu A,

- silną kontrolę zachowania z thumieniem gniewu i irytacji - przypominającą typ C.

Mówiąc o „osobowości psychosomatycznej”, należy mieć na względzie podobieństwo wzoru zachowania C do popularnego typu A (Mirski, 1998) lub typu D (O g iń sk a-B u lik, J u c z y ń s ki, 2007; O g ińs s a-B u lik, 2009).

Pojawiły się tezy, że charakterystyki opisane jako konstytuujące wzór zachowania typu $\mathrm{C}$ stanowią symptomy reakcji na stres poważnych lub przewlekłych schorzeń somatycznych, wzory obronno-adaptacyjnych zachowań i zmagania się z chorobą (por. Schwartz, za: Juczyński, 2002). Argumenty na rzecz przeciwstawnego stanowiska mogą być weryfikowane w wieloletnich badaniach longitudinalnych bądź przez wykazywanie stałości-ciagłości osobowości oraz spójności wzorów zachowania w biegu życia - zarówno przed wystapieniem choroby, jak i w reakcji na chorobę. Danych na rzecz tego ostatniego podejścia dostarczają teorie osobowości z kręgu nurtów psychodynamicznych, jak i wyniki badań empirycznych chorych somatycznie (np. Baltrusch, Waltz, 1985, 1986), również badania własne prowadzone pod kierunkiem autorki opracowania (K ubacka-Jas i ecka, Wy s ocka-Ple c zyk, 1998).

Powstaje natomiast pytanie, w jakim stopniu charakterystyki uwzględnione w badaniach można uznać za psychologiczny czynnik ryzyka rozwoju choroby? Narastająca współcześnie wiedza z zakresu psychologii zdrowia i choroby somatycznej przyjmuje istotną rolę psychologicznych czynników w etiologii wielu somatycznych chorób oraz ich wpływ na rozwój schorzenia. Wyniki badań prowadzonych $\mathrm{w}$ tym paradygmacie $\mathrm{w}$ zespole pod kierunkiem autorki wspierają w ogólnych zarysach tezy podejście psychosomatyczne, dostarczając równocześnie bardziej szczegółowych danych dotyczących wzajemnych zależności i mechanizmów.

Dotychczasowe wyniki naszych badań, w niewielkim zakresie dotychczas publikowane, zwracają uwagę na nowe, interesujące aspekty występowania wzoru zachowania $\mathrm{C}$ również u osób zdrowych somatycznie. Dotyczą one z jednej strony uwarunkowań rozwojowych kształtowania się osobowości typu C, z drugiej - wielu istotnych zjawisk, korelatów charakterystyki WZC, poszerzających naszą wiedzę o jego mechanizmach i znaczeniu. Wśród czynników rozwojowych, determinujących kształtowanie specyficznych schematów osobowości czy/i wzorów zachowania istotną rolę zdaje się pełnią czynniki temperamentalne, rodzaj rodzinnych relacji przywiązania emocjonalnego wraz z ewentualnymi wczesnodziecięcymi doświadczeniami traumatycznymi oraz utrwalony $\mathrm{w}$ dzieciństwie sposób doświadczania i percepcji własnego ciała. 


\section{Rozwojowe uwarunkowania osobowości i wzoru zachowania typu C}

Na temperamentalno-rozwojowe uwarunkowania osobowości typu C zwraca bezpośrednio uwagę koncepcja i badania H. J. Eysencka. Wydaje się również zasadne odniesienie do pozostających w kręgu paradygmatu psychodynamicznego koncepcji przywiązania. Badania kliniczne osób z wczesnodziecięcymi doświadczeniami utraty, kształtującymi $\mathrm{m}$. in. negatywne doświadczanie ciała, rodzącymi problemy samooceny i tożsamości wraz z niestabilnością granic Ja, pozwalają na tworzenie hipotez dotyczących etiologii WZC. Poniżej zostaną bliżej scharakteryzowane czynniki, które były przedmiotem wielu wstępnych badań prowadzonych pod kierunkiem autorki artykułu.

\subsection{Wzór zachowania C w koncepcji H. J. Eysencka}

W ostatnim czasie badania H. J. Eysencka zaczęły się koncentrować na praktycznych implikacjach jego teorii, czyli zależnościach między wyróżnionymi czynnikami o charakterze tempteramentalno-konstytucjonalnym a predyspozycjami do schorzeń psychicznych, przestępczości oraz chorób somatycznych, głównie takich jak choroby wieńcowe i nowotworowe (Eysenck, 1994; Gro s s arth-M at i cek i in., 1988).

Według teorii Eysencka charakterystyki układu nerwowego wraz z wpływem środowiska determinują kształtowanie się podstawowych form osobowości i zachowania. Zalicza do nich: neurotyzm, ekstraintrowersję, psychotyzm i inteligencję.

Różnice indywidualne w poziomie ekstrawersji i introwersji związane są z siatkowatym układem aktywacyjnym (ARAS), powodującym wyższy poziom pobudzenia korowego u introwertyków niż ekstrawertyków, których cechuje wyższe hamowanie korowe (percepcyjne i motoryczne). Powoduje to większe zsocjalizowanie i szybsze reakcje warunkowe u introwertyków.

Różnice w zakresie neurotyzmu są determinowane przez układ limbiczny, podwzgórze i układ nerwowy. Pobudzenie tych struktur przez bodźce emocjonalne skutkuje pobudzeniem korowym. Powiązania pomiędzy pobudzeniem ARAS a wzbudzeniem układu autonomicznego (aktywacja) powoduja, że wysoki neurotyzm idzie $\mathrm{w}$ parze $\mathrm{z}$ wysokim pobudzeniem, a ekstrawersja z niskim.

Wyróżnione przez H. J. Eysencka wymiary osobowości, względnie stabilne w biegu życia, związane są z trzema rodzajami problemów adaptacyjnych: towarzyskością (związaną z poczuciem samotności), emocjonalnością (związaną z neurotyzmem), wrogością i agresywnością jako składnikami psychotyzmu (K. Madsen, 1980; M. Zuckerman, 1989; za: B r z o z o w s k i, D rw a 1, 1995).

Nawiązując do badań psychosomatyków, R. Grossartha-Maticka i in. (1988), H. J. Eysenck mówił o trzech typach osobowości: A - o skłonności 
do choroby wieńcowej serca, B - typie zdrowym i C - ze skłonnością do chorób nowotworowych.

R. Gro s s arth-M at i cek, H. J. Ey s en ck i H. Vetter w 1988 r. wyodrębnili cztery typy reagowania na stres:

- typ 1: podminowanie (Understimulation),

- typ 2: nadmierne pobudzenie (Overarousal),

- typ 3: ambiwalencja (Ambivalence),

- typ 4: autonomia osobista (Personal Autonomy).

Dla typu 1 i 2 stres jest nieunikniony i prowadzi do schorzeń psychosomatycznych. H. J. Eysenck, charakteryzując osobowość typu C jako uwarunkowaną temperamentalnie, uwzględnił jej pozycję na wyróżnionych przez siebie wymiarach - ekstraintrowersji oraz zrównoważenia-niezrównoważenia (neurotyzm) (E y s e n c k, 1994; B r z o z o w s ki, Drwa 1, 1995).

Osoby typu 1, neurotyczne i intrawertywne, utożsamiane $\mathrm{z}$ typem $\mathrm{C}$, charakteryzuje poirytowanie i bezradność oraz bardzo silna zależność od ważnego emocjonalnie obiektu, którego obecność warunkuje szczęście i pomyślność. Brak lub utrata obiektu są przeżywane jako trauma. Osoba taka szuka bliskości z obiektem, reagując bezradnością i poczuciem beznadziejności na niepowodzenie swoich pragnień. Przeżywa stres, jeżeli nie udaje jej się zbliżyć do cenionego obiektu, nie odnosi sukcesu w pracy itp. Osoby takie reprezentują typ C osobowości; cechuje je skłonność do choroby nowotworowej. Typ 2 to neurotyczni ekstrawertycy, których charakteryzuje nadmierne pobudzenie. Dla tych osób ważne obiekty stanowią źródło stresu i nieszczęść. Odrzucenie przez obiekt bądź też niepowodzenie w jego zdobyciu skutkują przeżyciami o charakterze traumatycznym. Ciaghy kontakt z zaburzającymi normalne funkcjonowanie osobami i sytuacjami (np. zawodowymi) powoduje nasilanie się zależności. Nie mogąc uwolnić się od obiektu, osoby te przeżywają złość, agresję i silne pobudzenie. Są to osoby o osobowości typu A, o skłonności do choroby wieńcowej.

Zrównoważony, normalny typ, o średnim poziomie introwersji i ekstrawersji - typ 4 - odpowiadający typowi B, reprezentuje zdrowie i autonomię (Gros sarth-M a ticek i in., 1998).

\subsection{Problematyka relacji i więzi z matką}

Teoria przywiązania nawiązuje do tradycji psychoanalitycznej i teorii relacji z obiektem, a także założeń i obserwacji etologów. J. B o w lb y (2007) wysunął hipotezę, że reakcja przywiązania ma również u ludzi charakter instynktowny i autonomiczny. Przywiązanie to instynktowna, oparta na mechanizmach biologicznych, głęboka więź uczuciowa pomiędzy dzieckiem a opiekunem; zachowania świadczące o przywiązaniu występują naturalnie, są przystosowawcze, mają na celu osiągnięcie lub przedłużenie bliskości z osobą znacząca, 
zazwyczaj matką. Rozwój relacji wczesnodziecięcego przywiązania odbywa się przez całe życie, w trakcie którego zmieniają się figury przywiązania.

Pierwsze wczesnodziecięce doświadczenie i charakter relacji z opiekunem rzutują na wzory przywiązania $\mathrm{w}$ dalszych okresach życia. Znaczenie ma postawa opiekuna, częstość i jakość wzajemnych kontaktów - jego reaktywność wobec potrzeb fizjologicznych i potrzeby bliskości, pozwalająca dziecku na kształtowanie więzi z opiekunem. Adekwatne reagowanie na potrzeby dziecka, a także dostępność i reaktywność opiekuna stanowią źródło poczucia bezpieczeństwa dziecka i rozwijania aktywności eksploracyjnej. Z czasem obserwacja zachowań matki i czynników je determinujących prowadzi do utrwalenia się relacji o charakterze partnerskim (B owlby, 2007; Holmes, 2007). Dalszy rozwój relacji przywiązania skutkuje dojrzałością i kompetencją w funkcjonowaniu społecznym.

Bowlby podkreślał negatywne konsekwencje zaburzeń w rozwoju przywiązania, a zwłaszcza destruktywną w skutkach deprywację matczyną. Sytuacja utraty matki staje się wyznacznikiem zaburzeń - źródłem pojawiania się gniewu i lęku. Szczególne znaczenie ma możliwość wyrażania gniewu, w przeciwieństwie do jego wypierania, określająca dalsze relacje z rodzicami. Nawet krótkotrwała rozłąka z rodzicem, jak również powierzchowność lub niedopasowanie kontaktów mogą powodować trwające dłużej konsekwencje rozwojowe.

Zdaniem Bowlby'ego, analiza większości problemów psychicznych dorosłych prowadzi do wniosku o występowaniu w dzieciństwie traumatycznych doświadczeń wczesnodziecięcej rozłąki i żałoby, mających charakter lęku separacyjnego. W wieku dorosłym obawy, cierpienie, napięcie oraz „gniewny protest" połączone z niestrudzonym poszukiwaniem utraconej osoby, a wreszcie z dezorganizacją i rozpaczą, wskazuja, że wczesna rozłąka może trwale nasilać lęk i tendencje depresyjne na poziomie neurofizjologicznym (H o $1 \mathrm{~m}$ e s, 2007).

M. D. S. Ainsworth (Ainsworth, 1969; Ainsworth i in., 1978), współpracowniczka Bowlby’ego, wyróżniła trzy typy wzorców przywiązania (uzupełnione później o czwarty) uwzględniające obok aspektu relacyjnego również temperamentalny; zaobserwowała zróżnicowanie wzorców przywiązania do matki i ojca, przy czym te pierwsze mają w rozwoju bardziej znaczącą rolę. Wyróżnione typy wzorców obejmują przywiązanie: ufne, lękowounikające, lękowo-ambiwalentne i lękowo-zdezorganizowane. Wzorce przywiązania są stosunkowo trwałe, mimo iż z biegiem życia zmieniają się figury przywiązania. Wzorce rzutują na sposób interpretowania rzeczywistości, reagowania, relacje $\mathrm{z}$ innymi ludźmi.

Przedstawione poniżej zestawienie ilustruje, jak styl relacji w dorosłości powtarza oporne na zmiany schematy więzów wczesnego dzieciństwa. 


\begin{tabular}{|l|l|}
\hline \multicolumn{1}{|c|}{ Styl przywiązania dziecka } & \multicolumn{1}{c|}{ Styl przywiązania dorosłego } \\
\hline Bezpieczny & $\begin{array}{l}\text { Bezpieczny, Autonomiczny, Adekwatne } \\
\text { interakcje przywiązania }\end{array}$ \\
\hline Unikający (obojętność emocjonalna) & $\begin{array}{l}\text { Odsuwający się - unikanie przywiązania, } \\
\text { odrzucanie innych }\end{array}$ \\
\hline $\begin{array}{l}\text { Oporny lub ambiwalentny (stres, zaabsorbo- } \\
\text { wanie opiekunem, przylepność) }\end{array}$ & $\begin{array}{l}\text { Zaabsorbowany przeszłością, agresja, „za- } \\
\text { cieranie” granic Ja }\end{array}$ \\
\hline $\begin{array}{l}\text { Zdezorganizowany/zdezorientowany (ofiary } \\
\text { maltretowania, doświadczenie pojednania) }\end{array}$ & $\begin{array}{l}\text { Nierozwiązany/zdezorganizowany lękowy wo- } \\
\text { bec doświadczeń traumy, chwilowe dysocja- } \\
\text { cje, bliscy wpisani w traumę przeszłości }\end{array}$ \\
\hline
\end{tabular}

Rys. 1. Zależności między stylami przywiązania dziecka a dorosłego

Źródło: opracowanie własne na podst.: A in s w orth, 1969; A ins w orth i in., 1978.

Opisywane przez Bowlby’ego i jego następców konsekwencje zaburzonej wczesnodziecięcej relacji z matką są zasadniczo zbieżne z koncepcją H. J. F. Baltruscha (Baltrusch, Waltz, 1985, 1986) psychosomatycznej etiologii schorzeń nowotworowych. Podkreśla ona znaczenie matczynej deprywacji doświadczenia utraty, kształtowania się wzorców emocjonalno-poznawczych w wyniku nieprawidłowej wczesnodziecięcej relacji oraz trudności radzenia sobie z negatywnymi emocjami. Konsekwencją nieprawidłowo ukształtowanych więzi może być depresja, izolacja, poczucie bezradności, niska samoocena, wysoki poziom napięcia. Można również mówić o nieumiejętności adekwatnej retrospektywnej oceny więzi i braku możliwości wykorzystania ewentualnego potencjału wsparcia społecznego w sytuacjach stresowych i kryzysowych (por. Holm e s, 2007).

Na podstawie badań wywodzących się z nurtu przywiązania, można stwierdzić, że osoby, które utraciły matkę w okresie wczesnodziecięcym, częściej doświadczają utraty w późniejszym życiu, a równocześnie nie mają dostępu do wsparcia społecznego. Badania wskazują ponadto na rolę wzorca przywiązania w genezie mniej lub bardziej patologicznych form osobowości.

Charakterystyka wzoru zachowania $\mathrm{C}$ wykazuje zbieżność $\mathrm{z}$ właściwościami wzorców zachowania o charakterze lękowym, lękowo-unikowym, z nieumiejętnością ekspresji uczuć, a także pozorną, fasadową niezależnością, wytrzymałością i samowystarczalnością.

\subsection{Percepcja i doświadczanie Ja cielesnego}

Rozważania nad Ja cielesnym obejmują dwa aspekty: podmiotowy - odbijający świadomość własnego Ja - i przedmiotowy - percypujący wizerunek ciała (M i r u k a, 2003). Ja cielesne odgrywa doniosłą rolę w procesie kształtowania się osobowości i tożsamości jednostki (por. Ja mes, 1890; A 11 p ort, 1988; 
Tucholska, 1997). Ja cielesne - poczucie własnego ciała - jest tworzone przez strumień doznań płynących $\mathrm{z}$ wnętrza organizmu, a ono samo stanowi gwarancję poczucia odrębności ciała i świadomości jego funkcji. Ja cielesne stanowi kotwicę samoświadomości i tożsamości - rdzeń, wokół którego kształtują się pozostałe podsystemy osobowości. Dlatego zaburzenia Ja cielesnego prowadzą do nieprawidłowości w obrębie całego systemu, a warunkiem prawidłowego funkcjonowania jest integralność obu aspektów: Ja - cielesnegoprzedmiotowego i Ja - podmiotowego (Kow alik, 2003; Ca sh-Pruziński; 2004; Grog a n, 2008).

M. Mahler w swojej koncepcji (S o k o li k, 1988, 1993) uznała rozbicie systemu Ja za konsekwencję wczesnodziecięcych rodzinnych doświadczeń, w szczególności braku empatycznych relacji i niepowodzeń w zakresie więzi z matką, zaburzających proces separacji dziecka. Przejście czterech faz rozwoju prowadzi do ukształtowania Ja cielesnego, wraz z ustabilizowaniem jego granic; warunkiem rozwoju jest dobra opieka macierzyńska, empatia, emocjonalna dostępność matki wraz z akceptacją dążeń dziecka do autonomii. Izolacja dziecka, negowanie przejawów jego odrębności, nadmierna uległość matki lub przesadna opiekuńczość zaburzają proces separacji - wyodrębniania własnego Ja - jak również późniejsze funkcjonowanie dziecka jako osoby dorosłej, przejawiającej silne tendencje zależności (symbiotyczne).

Koncepcja O. Kruegera (za: Miru cka, 2003) charakteryzuje fazy kształtowania się obrazu ciała. W fazie początkowej internalizacja doświadczenia ciała odbywa się w okresie przedwerbalnym; fragmentaryczne, negatywne, traumatyczne doznania wraz z ich niewerbalnymi reprezentacjami psychicznymi zostają zintegrowane $\mathrm{w}$ zaburzonych, nieświadomych schematach ciała. $\mathrm{W}$ fazie drugiej ustanawianie granic ciała wraz $\mathrm{z}$ rozpoznawaniem i wyodrębnieniem wewnętrznych stanów fizjologicznych pozwala na rozwój coraz bardziej spójnego obrazu ciała (body image). Różnicowanie między ciałem własnym a matki pozwala na ustanawianie granic między przestrzenią własną a otaczającym światem. Synchronia matka - dziecko stanowi warunek ukształtowania pozytywnego poczucia własnej wartości i kompetencji, a przede wszystkim integracji Ja cielesnego i psychicznego, gwarantującej spójne pozytywne poczucie tożsamości (S h a k er, Rubin st e in, 1980).

W koncepcji M. Klein (za: S e g a 1, 2005) brak gratyfikujących doświadczeń w kontakcie z matką powoduje utrwalanie się pierwotnych mechanizmów obronnych odpowiadających za niezdolność przeżywania siebie jako odrębnej całości. W rezultacie brakuje spójnej reprezentacji matki (łączącej cechy dobrego i złego obiektu). Skutkuje to zależnością od matki w dorosłości, a utrata matki lub osób będących jej substytutami - zarówno realna, jak i wyobrażona stanowi poważne zagrożenie dalszego rozwoju. Związki emocjonalne z osobami 
znaczącymi stają się nacechowane dystansem, ambiwalencją i ukrytą wrogością (por. Zalewska, 2003; S ok olik, 1988).

Nieprawidłowe relacje matki i dziecka wpływają na trudności integracji ciała i umysłu oraz doświadczanie świata w nierozłącznych kategoriach poznawczo-emocjonalnych. Własne ciało odczuwane jako nie-Ja jest traktowane jako substytut matki. Zapoczątkowuje to proces tzw. triangulacji ciała, które pełni rolę swoistego medium, przedmiotu, narzędzia, poprzez które są rozładowywane napięcia i lęki mające źródło w relacjach $\mathrm{z}$ matką. Nie jest doświadczane jako należące do zintegrowanego Ja, przeżywane jako odrębne od Ja psychicznego. Własne ciało może się stać przedmiotem manipulacji, narzędziem dyscyplinowania Ja, somatyzacji, wyrażania agresji lub autoagresji.

Rozważania badaczy na temat wzoru zachowania $\mathrm{C}$ sugerują, że u osób o tym typie osobowości występuje silna potrzeba zależności, a utrata osób znaczących jest przeżywana jako utrata części Ja (por. np.: L e S ha n, W o r thington, 1956; Baltrusch, Waltz, 1985, 1986). Osoby WZC są silnie uzależnione od stanu emocjonalnego partnera, cechuje je skrajna uległość (ewentualnie silne dążenie do dominacji i uzależnienia partnera), a negatywne doświadczanie ciała może stanowić podstawę ryzyka psychosomatycznego radzenia sobie z konfliktami poprzez ich somatyzowanie.

\section{Wstępne wyniki badań nad rozwojowymi uwarunkowaniami wzoru zachowania $\mathbf{C}$}

Poniżej zostaną przedstawione wybrane wyniki wstępnych badań prowadzonych w Zakładzie Interwencji Kryzysowej i Psychoterapii IPS UJ pod kierunkiem autorki artykułu. Wyniki badań weryfikujące niektóre z przedstawionych wyżej tez piśmiennictwa pochodzą z kilku odrębnych studiów, wykorzystujących z uwagi na nowatorski charakter badań rozmaite narzędzia badania.

Wzór zachowania C badano kwestionariuszem WZC, opracowanym dla celów badań ${ }^{1}$. Zastosowana wersja składa się z 70 itemów tworzących 10 skal odpowiadających podstawowym wymiarom przypisywanym wzorowi zachowania C; $\alpha$-Cronbacha obliczona dla całej skali wynosi $-0,853$.

${ }^{1} \mathrm{~W}$ wykorzystanych publikacjach autorka nie znalazła żadnego narzędzia służącego do pomiaru poziomu WZC. Opracowano kwestionariusz własny, weryfikując kolejne wersje; ostatnia z nich została ostatecznie skonstruowana i znormalizowana przez Martę Majewską. 


\subsection{WZC w badaniach populacyjnych}

Przedstawione wyniki pochodzą $\mathrm{z}$ dwu studiów, w których badano osoby zdrowe. Rozkład wyników WZC w populacji osób zdrowych somatycznie $\mathrm{w}$ badaniu przeprowadzonym na 310 badanych (studia 5 i 6$)^{2} \mathrm{w}$ wieku $20-50$ lat nie odbiega istotnie od rozkładu normalnego $(p \geq 0,05)$.

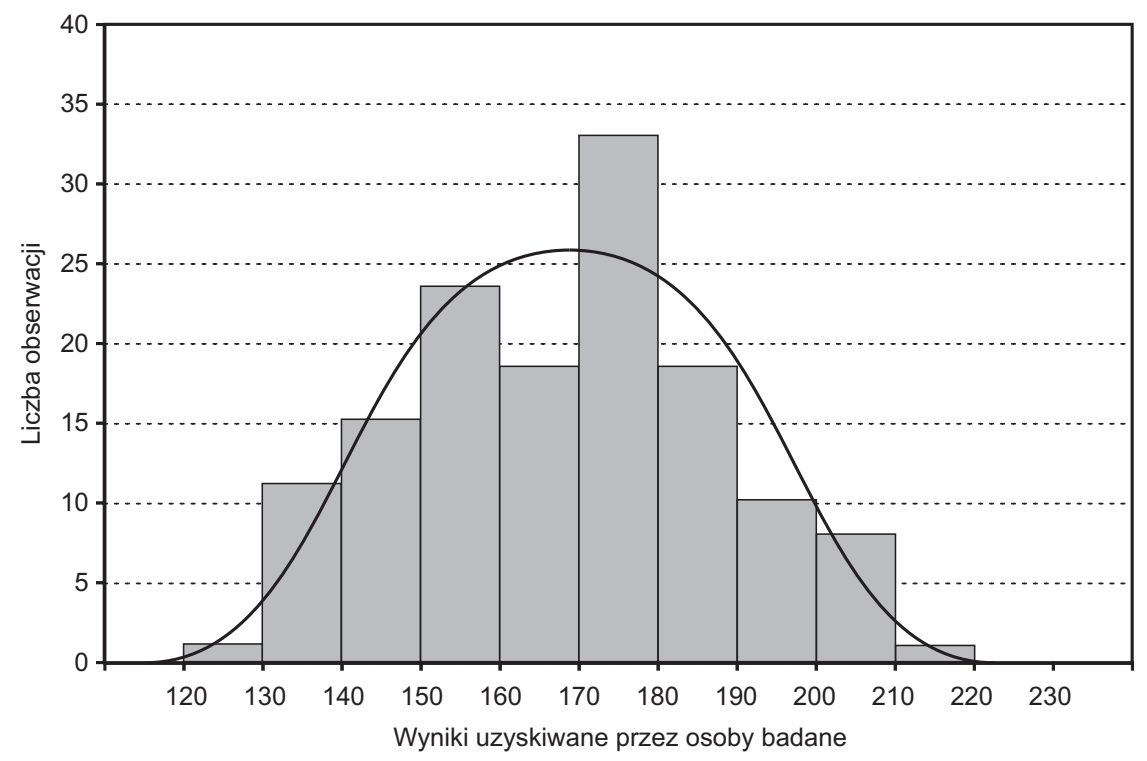

Źr ó d ło: opracowanie własne.

Rys. 2. Rozkład wyników testu TPC

Proporcje w grupie WZC (studium $6, N=139$, kobiety) uwzględniające zmienne demograficzne przedstawiają się następująco:

- wiek 20-34 lata - 65\%; 34 lata i powyżej-35\%;

- wykształcenie podstawowe - $12 \%$; średnie - $57 \%$; wyższe - $31 \%$;

- stan cywilny wolny $-69 \%$; mężatki - 31\%;

- kobiety bezdzietne $-62 \%$; posiadające potomstwo $-38 \%$;

- miejsce zamieszkania: miasto $-65 \%$; wieś $-35 \%$.

${ }^{2}$ Badania przeprowadziły i opracowały: Katarzyna Myga (studium 5) oraz Marta Majewska (studium 6). 


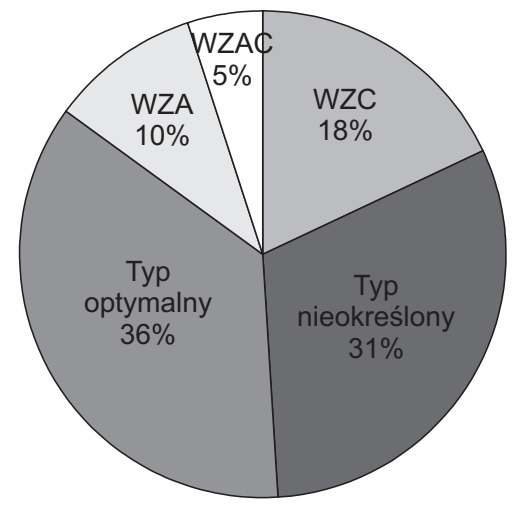

Rys. 3. Rozkład typów osobowości w procentach, w grupie osób zdrowych somatycznie

Źr ódło: opracowanie własne.

Uw a g a: wyniki studium 5: $N=233$ - osoby zdrowe somatycznie (kobiety $(N=180)$ 77\%, mężczyźni $(N=53)$ - 23\%). WZA - pomiar Kwestionariuszem Sposób Życia

C. D. Jenkinsa, Typ Optymalny i WZAC - Testem Psychosomatycznym A. Mirskiego.

Osoby o typie WZC $(N=43-18 \%)$ i WZAC $(N=11-5 \%)-$ stanowią łącznie $23 \%$ badanej grupy.

\subsection{Wyniki badań - nurotyzm i ekstrawersja a WZC}

Wyniki badań kwestionariuszem Eysencka przedstawiono w tab. 1 .

Tabela 1

Wyniki kwestionariusza Eysencka kobiet chorych somatycznie (studia 2, 4)

\begin{tabular}{|c|c|c|c|c|c|c|c|c|c|c|c|}
\hline \multicolumn{2}{|c|}{$\begin{array}{c}\text { Studium/Grupa } \\
\text { N E=WK }\end{array}$} & \multicolumn{3}{c|}{ Ekstrawersja } & \multicolumn{4}{c|}{ Neurotyzm } & \multicolumn{3}{c|}{ Kłamstwo } \\
\hline \multicolumn{2}{|c|}{ Nr } & E & K & ,t” & E & K & „t” & E & K & „t” \\
\hline $4^{a}$ & RZS & 41 & 5 & 6 & ni & $\mathbf{6}$ & $\mathbf{3}$ & $\mathbf{0 , 0 5}$ & 6 & 5 & ni \\
\hline $2^{b}$ & RZS & 30 & 5 & 5 & ni & $\mathbf{6}$ & $\mathbf{4}$ & $\mathbf{0 , 0 1}$ & $\mathbf{7}$ & $\mathbf{4}$ & $\mathbf{0 , 0 2}$ \\
\hline
\end{tabular}

${ }^{a}$ Badania przeprowadziła i opracowała Małgorzata Hodurek (studium 4).

${ }^{b}$ Badania przeprowadziła i opracowała Sawrina Stopyra (studium 2).

ni - nieistotne. 
Badane ze schorzeniem reumatoidalnego zapalenia stawów z grup RZS cechuje neurotyzm na poziomie nieco powyżej średniej, istotnie wyższy od grup kontrolnych. Mniej niż średni poziom ekstraintrowersji nie różnicuje grupy eksperymentalnej i kontrolnej (średnia skali wynosi 5,5 stena). Graficzną ilustrację otrzymanych wyników istotnych wraz z pozycją typu 1 Eysencka przedstawiono na rys. 4.

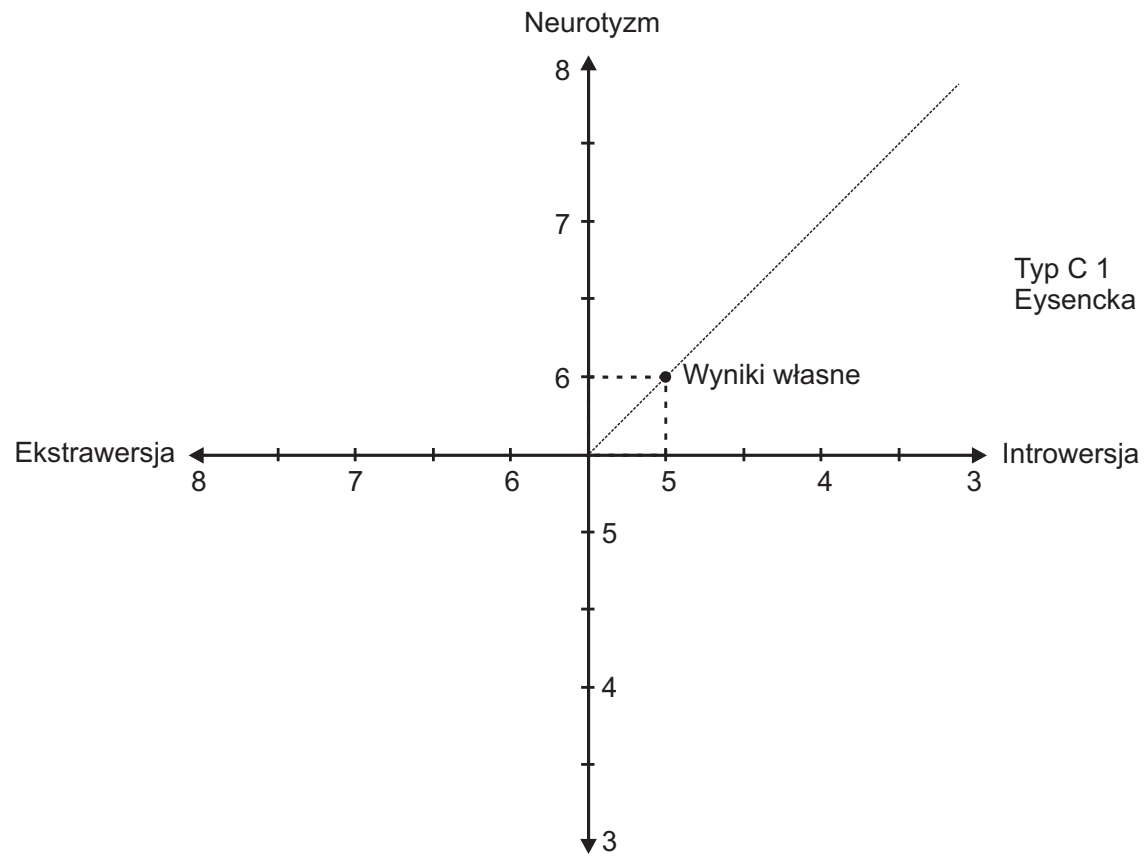

Rys. 4. Wyniki badań a hipoteza Eysencka (typ 1)

Źródło: opracowanie własne.

Wyniki obu studiów potwierdzają hipotezę H. J. Eysencka dotyczącą pozycji typu 1 (C) na współrzędnych neurotyzm - introwersja. Osoby z wzorem zachowania C (typ 1) różnią się w sposób statystycznie istotny od grup kontrolnych poziomem neurotyzmu, realizując wzór - neurotyczny introwertyk, przy lekko podwyższonym neurotyzmie i lekko obniżonym (prawie średnim) poziomie introwersji. Wyniki skali kłamstwa zgodne z innymi danymi naszych badań wskazują na tendencję do fasadowego pokazywania się w lepszym świetle (studium 2). 


\subsection{Więzi i relacje $\mathrm{z}$ matką}

W poniżej przedstawionych badaniach obraz relacji i więzi z matkami weryfikowano w kolejnych studiach za pomocą różnych narzędzi badań: kwestionariusza Stosunków Między Rodzicami a Dziećmi A. Roe i M. Siegelman (PCR), Kwestionariusza Retrospektywnej Oceny Postaw Matki M. Plopy (KRP RocM), Kwestionariusza Parental Bonding Instrument (G. Parkera, H. Turpira, L. B. Browna) oraz wybranych członów Testu Zdań Niedokończonych L. Sidneya, J. M. Sachsa.

W studium ${ }^{3} 3$, które objęło kobiety po zabiegu mastektomii uczestniczące w spotkaniach organizowanych przez kluby „Amazonek” (czas od zabiegu mastektomii od 1 roku do 6 lat), badano percepcję osoby matki i jej postawy wobec byłych pacjentek w okresie wczesnodziecięcym, oceniane z perspektywy dorosłego, jak również przeżywanie konfliktu „wokół postaci matki”, sygnalizowanego przez wielu badaczy wzoru zachowania C. Wyniki badanych po mastektomii nie różniły się w sposób istotny od wyników kobiet zdrowych, na wymiarach: chłodna - ciepła, wzbudzająca lęk - dająca bezpieczeństwo. Natomiast znaczące różnice $(p \leq 0,001)$ obejmują wymiar: siła i zaradność kobiety po mastektomii spostrzegają swoje matki jako bierne, niezaradne, słabe psychicznie.

Istotne różnice $\mathrm{w}$ relacjach $\mathrm{z}$ matką $(p \leq 0,01)$ uzyskano na podstawie analizy danych techniki uzupełniania zdań. Wskaźniki formalne konfliktów (brak odpowiedzi, przedłużony czas realizacji, zmiany udzielonej odpowiedzi, tzw. przepracowania) znalazły potwierdzenie w analizie treści wypowiedzi. Kobiety po zabiegu mastektomii prezentuja zdecydowanie bardziej negatywny obraz matki niż kobiety zdrowe, mają więcej pretensji, żalu i zarzutów, ujawniają poczucie krzywdy rzutujące na ocenę relacji z matką. Uważają że matki nigdy nie miały dla nich czasu i były życiowo niezaradne.

Częstsze od wypowiedzi negatywnych były takie, które wskazywały na nijaki, raczej wątly i słaby, kontakt byłych pacjentek ze swymi matkami. Pacjentki nie zawsze potrafiły się $\mathrm{z}$ matką porozumieć - ich poglądy w wielu kwestiach różniły się, opinie i postawy pacjentek nie znajdowały zrozumienia ani uznania matek, pacjentki czuły się zmuszone, aby ostatecznie, wbrew sobie, podporządkować swoje decyzje woli matki. Uderza stosunkowo duża liczba wypowiedzi unikowych, sugerujących niechęć uświadomienia sobie bądź ujawnienia konfliktowych relacji z matkami, brakuje natomiast wypowiedzi bardzo pozytywnych, pozbawionych nuty dezaprobaty, które nierzadko spotykamy w uzupełnieniach kobiet zdrowych (por. K u b a c k a-J a s i e c k a, 2006).

$\mathrm{W}$ tab. 2 przedstawiono korelacje między poziomem WZC a retrospektywną oceną matek.

\footnotetext{
${ }^{3}$ Badania wykonała i opracowała Beata Wójtowicz (grupa eksperymentalna kobiet po mastektomii $-N=29$, kontrolna $-N=29$; wiek badanych $-30-80$ lat, średnia wieku $-52,3$ lat).
} 
Korelacje WZC z retrospektywną oceną relacji z matką (studium 6, osoby zdrowe somatycznie)

\begin{tabular}{|l|c|c|c|}
\hline \multicolumn{1}{|c|}{ Skala } & $r$ & Istotność & $\begin{array}{c}\text { Wyjaśniana wariancja } \\
(\mathbf{\%})\end{array}$ \\
\hline Odrzucenie & $\mathbf{0 , 3 6}$ & $\mathbf{0 , 0 1}$ & $\mathbf{1 2}$ \\
\hline Brak autonomii & 0,30 & 0,01 & 6 \\
\hline Nadmierne wymagania & 0,26 & 0,01 & 8 \\
\hline $\begin{array}{l}\text { Niekonsekwencja wycho- } \\
\text { wawcza }\end{array}$ & 0,29 & 0,01 & 7 \\
\hline $\begin{array}{l}\text { Brak dbałości o dobrostan } \\
\text { fizyczny }\end{array}$ & 0,27 & 0,01 & 8 \\
\hline
\end{tabular}

Występują bardzo istotne korelacje, choć niewysokie, między WZC a niekorzystną relacją z matką. Najbardziej znacząca korelacja dotyczy związku wysokiego poziomu WZC z odrzuceniem przez matkę.

Natomiast wyniki ${ }^{4}$ studium 8 nie potwierdzają zależności między poziomem WZC a brakiem opieki ze strony matki i ojca, a także nasileniem kontroli ze strony rodziców u chorych onkologicznie.

\subsection{Wyniki badań nad percepcją i doświadczaniem ciała}

Przedstawione poniżej wyniki pochodzą z dwu studiów: w studium 5 wykorzystano skalę BIS, w studium 6 - skale BIS i BES. W tab. 3 i 4 zawarto wyłącznie wyniki statystycznie istotne.

Tabela 3

Skala zaangażowania wobec ciała J. Orbach, M. Mikulincer BIS (studium 5, $N=233, \mathrm{~K}+\mathrm{M}$, metoda porównań wielokrotnych LSD)

\begin{tabular}{|c|c|c|c|}
\hline Skala BIS & $\begin{array}{c}\text { Samooceny w grupie } \\
\text { WZC }\end{array}$ & Porównanie $^{a}$ & Istotność \\
\hline $\begin{array}{l}\text { Uczucia i postawy wobec } \\
\text { ciała }\end{array}$ & negatywne & $\mathrm{WZC}=\mathrm{WZAC}<\mathrm{WZA}$ & 0,01 \\
\hline $\begin{array}{l}\text { Komfort w kontakcie } \\
\text { fizycznym z innymi }\end{array}$ & negatywny & WZC $<$ WZA, WZAC & 0,01 \\
\hline
\end{tabular}

${ }^{a}$ Porównanie z grupami WZA i WZAC (wzór mieszany o cechach zarówno WZA, jak i WZAC).

${ }^{4}$ Badania przeprowadzał $\mathrm{z}$ zastosowaniem kwestionariusza Parental Bonding Instrument (G. Parker, H. Turpin, L. B. Brown) Łukasz Małecki. 
Grupę WZC cechują negatywne postawy i uczucia wobec ciała; badani przeżywają również większy dyskomfort $\mathrm{w}$ kontakcie fizycznym $\mathrm{z}$ innymi ludźmi - istotnie różniący tę grupę od pozostałych.

Zależności między WZC a BiS (studium 6)

\begin{tabular}{|l|c|c|c|}
\hline \multicolumn{1}{|c|}{ Skala } & $r$-Pearsona & $\begin{array}{c}\text { Poziom } \\
\text { istotności }\end{array}$ & $\begin{array}{c}\text { Wyjaśniana } \\
\text { wariancja (\%) }\end{array}$ \\
\hline Uczucia i postawy wobec ciała & $-0,48$ & 0,01 & 22 \\
\hline Komfort w kontakcie fizycznym z innymi & $-0,22$ & 0,01 & 5 \\
\hline
\end{tabular}

W tab. 4 występują następujące zależności:

- wysoki poziom WZC koreluje $\mathrm{z}$ negatywnymi uczuciami i postawami wobec ciała,

- wysoki poziom WZC koreluje z niskim komfortem w kontakcie fizycznym z innymi.

W tab. 5 przedstawiono wyniki skali samooceny ciała BES (L. Franzoe, S. A. Shields) zarówno w wymiarach ogólnych, jak i szczegółowych.

Wyniki skali BES ${ }^{a}$

\begin{tabular}{|l|l|l|c|}
\hline \multicolumn{1}{|c|}{ Wymiary ogólne } & $\begin{array}{c}\text { Samooceny w grupie } \\
\text { WZC }\end{array}$ & \multicolumn{1}{|c|}{ Porównanie } & $\begin{array}{c}\text { Istotność różnicy } \\
\text { między WZC a WZCA } \\
\text { i WZA }\end{array}$ \\
\hline \multicolumn{3}{|c|}{ Mężczyźni } \\
\hline Fizyczna atrakcyjność & średnia & WZC $<$ WZA, WZAC & 0,05 \\
\hline Siła fizyczna & negatywna & WZC $<$ WZA, WZAC & 0,01 \\
\hline $\begin{array}{l}\text { Kondycja fizyczna } \\
\text { (sprawność) }\end{array}$ & \multicolumn{1}{|c|}{ negatywna } & WZC $<$ WZA, WZAC & 0,01 \\
\hline \multicolumn{4}{|c|}{ Kobiety } \\
\hline Atrakcyjność seksualna & negatywna & WZC $<$ WZA, WZAC & 0,05 \\
\hline Troska o wagę & negatywna & WZC $<$ WZA, WZAC & 0,05 \\
\hline Sprawność fizyczna & negatywna & WZC $=$ WZA $=$ WZAC & ni \\
\hline
\end{tabular}

${ }^{a}$ Wyniki opracowano stosując test porównań wielokrotnych LSD.

ni - nieistotne. 
Podsumowując, w grupie WZC samooceny ogólne swojego ciała (jak i wymiary szczegółowe) są istotnie bardziej negatywne i niższe niż w pozostałych grupach. Wyjątek stanowią oceny atrakcyjności i sprawności fizycznej, pozostające na poziomie średnim i niskim, ale nie różniące się od samoocen pozostałych badanych grup.

\section{Podsumowanie wyników i wnioski}

Spróbujmy pokrótce podsumować przedstawione wyniki oraz sformułować nasuwające się wnioski. Podsumowując:

1) w świetle opracowanego kwestionariusza WZC wzór zachowania typu $C$ jest zmienną o rozkładzie w populacji przybliżonym do normalnego. Występuje (łącznie z typem mieszanym - WZAC) u ok. 25\% badanej, stosunkowo dużej grupy osób zdrowych somatycznie; pozwala to wnioskować, że jest to wzór zachowania występujący stosunkowo powszechnie w populacji. Tym samym przedstawione wstępne wyniki badań zaprzeczają hipotezom traktującym WZC wyłącznie jako reakcję na poważne, ciężkie stany chorób somatycznych;

2) osoby badane o wzorze zachowania typu C realizują typ 1 (C) H. J. Eysencka - neurotyczny introwertyk - choć w niewielkim nasileniu, zwłaszcza introwersji (graniczne wyniki intro- i ekstrawersji);

3) Na podstawie wyników badań osób po mastektomii oraz osób zdrowych somatycznie rysuje się stosunkowo złożony obraz relacji badanych o wzorze zachowania $\mathrm{C}$ z matką. Konfliktom „wokół postaci matki” towarzyszy idealizacja postaci rodziców:

- wyniki kwestionariuszowe wskazują na istotne różnice w ocenie matki; badane po mastektomii spostrzegają swoje matki jako bierne, niezaradne i słabe psychicznie. Występują istotne zależności między nasileniem WZC a retrospektywną oceną postawy matek w dzieciństwie; oceny badanych mówią o braku autonomii, nadmiernych wymaganiach, niekonsekwencji w wychowaniu, braku dbałości o dobrostan fizyczny dziecka, szczególnie jednak dotyczą poczucia odrzucenia przez matkę;

- wyniki metody projekcyjnej - zarówno tzw. wskaźniki formalne, jak i analiza treści - świadczą o pretensjach, żalach, poczuciu krzywdy, wzajemnej obojętności, występowaniu konfliktów i despotycznej dominacji matek. Negatywne oceny są $\mathrm{w}$ znaczącej mierze thumione i ukrywane, zwłaszcza przez kobiety zdrowe ze wzorem zachowania typu C.

4) wyniki badań dotyczące percepcji i doświadczenia ciała wskazują na zdecydowanie negatywne postawy i uczucia wobec ciała osób o wzorze zachowania typu $\mathrm{C}$, a także przeżywanie dyskomfortu w kontakcie $\mathrm{z}$ innymi. Samooceny własnego ciała - zarówno ogólne, jak i szczegółowe - są zdecydowanie 
negatywne (z wyjątkiem atrakcyjności i sprawności fizycznej) oraz istotnie niższe niż w grupach o wzorze mieszanym (WZAC) i wzorze zachowania A.

$\mathrm{Na}$ koniec, nawiązując do referowanych rozważań teoretycznych, należy przedstawić nasuwające się wnioski i refleksje. Do ukształtowania wzoru zachowania C obok czynników temperamentalnych przyczyniają się wczesnodziecięce doświadczenia zaburzające prawidłowy rozwój struktury osobowości. Obserwowane w dorosłości dysfunkcjonalne doświadczanie swojego ciała, jego negatywna, wyróżniająca osoby o typie osobowości i zachowaniu typu $\mathrm{C}$, samoocena wydaje się zdeterminowana charakterem wczesnodziecięcych doświadczeń i relacji z matką. O zaburzonych relacjach przywiązania w dzieciństwie rzutujących na funkcjonowanie w dorosłości oraz łączących $\mathrm{z}$ nią aktualnych ambiwalentnych więziach świadczą wybrane wyniki badań wskazujące na negatywną retrospektywną ocenę postaci matki badanych o typie C. Więzi zdecydowanie konfliktowych, nacechowanych postawą buntu i ukrywanej pod fasadą idealizacji - wrogości. Teoria psychopatologii takie obronno-adaptacyjne postawy wiąże z konsekwencjami kosztów przystosowania dziecka do przetrwania w rodzinie, mogą one jednak stanowić czynnik ryzyka wystapienia w przyszłości schorzeń psychosomatycznych.

Właściwości osobowości i zachowania charakteryzujące WZC można w pewnej mierze uznać za przejaw niedojrzałości emocjonalnej; zwraca uwagę częstość występowania wzoru w młodszej populacji, do 34 lat, a także u osób niezamężnych i nieposiadających potomstwa. Wspierają one pośrednio wyniki sugerujące niedojrzały charakter obronno-adaptacyjny wzoru zachowania $\mathrm{C}$. Negatywną percepcję postaci i relacji z matką można hipotetycznie wiązać z wczes nodziecięcą traumą i/lub prymitywnymi obronami i zaburzeniami we wczesnych fazach rozwoju, przejawiającymi się: trudnościami wyodrębniania Ja, integrowania obrazu złego i dobrego obiektu (matki), a także wyzwalania się z zależności i kształtowania autonomicznej, zintegrowanej tożsamości w okresie dorastania.

Nasuwa się ważny wniosek natury metodologicznej - w badaniach osób o wzorze zachowania C napotykamy trudności w zakresie nawiązania głębszego kontaktu z badanymi oraz problemy związane z dotarciem do ich wewnętrznej rzeczywistości. Właściwości osobowości oraz konfliktowe i ambiwalentne relacje z bliskimi są thumione oraz ukrywane za fasadą poprawności i idealizowania postaci rodziców. Stosowane obrony psychiczne pochodzące $z$ różnych poziomów kontinuum świadomości-nieświadomości utrudniają, a czasem wręcz uniemożliwiają bezpośrednie zbadanie dyspozycji osobowości oraz funkcjonujących mechanizmów zachowania. W badaniach WZC większą wiarygodność i wartość wydaje się mają nie techniki kwestionariuszowe, lecz metody obserwacyjne, projekcyjne, poznania środowiskowego i w ograniczonym zakresie jak to bywa w badaniach typu klinicznego - eksperymentalne, których stosowanie staje się swoistym wyzwaniem dla badacza. 
Przedstawione rezultaty badań ukazujące nowe mechanizmy osobowości i zachowania typu C należy oczywiście traktować z ostrożnością - opierają się na badaniach o charakterze wstępnym, obejmujących zebrane wyniki kilku studiów, prowadzonych na nierówno licznych grupach badanych, zwłaszcza stosunkowo niewielkich grupach chorych somatycznie, co nie pozwala na stosowanie bardziej złożonych procedur statystycznych. Ze względu jednak na charakter badań, otwierających nowe, szersze perspektywy przed badaczami zainteresowanymi osobowościami i wzorem zachowania typu $\mathrm{C}$, nie tylko w kontekście psychosomatycznym wydawało się zasadne pokazanie kierunku i drogi rozważań nad rozwojowymi uwarunkowaniami osobowości i wzoru zachowania typu $\mathrm{C}$, wytyczonych przez otrzymane skromne, ale zachęcające, rezultaty dotychczasowego wysiłku badawczego.

\section{Bibliografia}

A insworth M. D. S. (1969), Object relations, dependency and attachments: A theoretical review of the infant-mother relationship, „Child Development”, 40.

A insworth M., B lehar M., W aters E., Wall S. (1978), Patterns of attachment: assesea in strange situation and at home, Lawrence Erlbaum, New York.

A 11 p o r t G. W. (1988), Osobowość i religia, IW PAX, Warszawa.

B a $1 \mathrm{tru} \mathrm{s} \mathrm{ch} \mathrm{H.} \mathrm{J.} \mathrm{F.,} \mathrm{W} \mathrm{a} 1 \mathrm{tz}$ M. (1985), Cancer from behavioral and social epidemiological perspective, „Social Science Medicine”, 20.

B altrusch H. J. F., Waltz M. E. (1986/2007), Persobiological model of host-tumor relationship, [w:] J. B o w 1 b y (ed.), Przywiqzanie, Wydawnictwo Naukowe PWN, Warszawa.

B r z o z o w s k i P., D rw a 1 R. (1995), Kwestionariusz Osobowości Eysencka. Polska adaptacja $E P Q-R, \mathrm{PTP}$, Warszawa.

C a s h T. F., Pru z in s k y T. (2004), Body image: a handbook of theory, research and clinical practice, Guilford Press, London-New York.

D ol ińska-Z y g m unt G. (2001), Psychologiczne uwarunkowania chorób nowotworowych, [w:] G. D o 1 i ń s k a-Z y g m u n t (red.), Podstawy psychologii zdrowia, Wyd. Uniwersytetu Wrocławskiego, Wrocław.

E y s e n c k H. J. (1994), Cancer, personality and stress: prediction and prevention, „Advances in Behavior Research and Therapy", 16 (3).

Grogan S. (2008), Body image. Understanding body dissatisfaction in men, women and children, Routledge, New York.

Gro s s a r t h-M a t i c e k R., E y s e n c k H. J., V e t t e r H. (1988), Personality type, smoking habit and their interaction on predictors of cancer and coronary heart disease, „Personality and Individual Differences", 9.

H o 1 m e s J. (2007), John Bowlby, GWP, Gdańsk.

J a m e s W. (1890), Principles of psychology, Scribner, New York.

J u c z y ń s k i Z. (2002), Psychoonkologia jako dziedzina badań i praktyki klinicznej, „Psychoonkologia", 38 (6),

K o w a 1 i k S. (2003), Ja-cielesne - próba nowego spojrzenia, „Polskie Forum Psychologiczne”, 6, 1-2. 
$\mathrm{Kubacka-J}$ a s i cka D. (2006), Funkcjonowanie emocjonalne kobiet po mastektomii z perspektywy rozważań nad wzorem zachowania typu C (WZC), ,Sztuka Leczenia”, 13, 3-4.

K u b a c k a-J a s i e cka D., W y s o c k a-P l e c z y k M. (1998), Osteoporoza - wtaściwości psychiczne i funkcjonowanie pacjentek $w$ obliczu choroby, The Baltic Sea Conference of Psychosomatic Medicine, Szczecin.

L e S h a n L. L., W orth ingt on R. E. (1956), Personality as factor in the pathogenesis of cancer: A rewiew of the literature, „British Journal of Medical Psychology”, 29.

Mat thews G., A me lang M., Yousfi S., S chmidt-R a thjens C., Feld t K. (19961998), Personality variable differences between disease clusters, Psychologisches Institut, University of Heidelberg (Germany), raport z badan.

Mirski A. (1995), Udziat czynników psychologicznych w etiologii chorób nowotworowych, „Sztuka Leczenia”, 1 (1).

Mirski A. (1998), Optimum psychosomatyczne, [w:] J. Łazowski, D. Dolińska-Z yg munt (red.), Ku lepszemu funkcjonowaniu $w$ zdrowiu $i$ chorobie. Materiaty XIII Ogólnopolskiego Sympozjum Medycyny Psychosomatycznej i V Battyckiego Sympozjum Balintowskiego, Kolobrzeg, maj 1997, Wydawnictwo AWF, Wrocław.

M i r u c k a B. (2003), Ja-cielesne fundamentem osobowości, „Forum Psychologiczne”, 8, 1-2.

M or r is T., G r e e r S., P e t t in g a l e K. W., W a t s o n M. (1981), Patterns of expression of anger and their psychological correlates in woman with breast cancer, „Journal of Psychosomatic Research", 2.

Og ińska-B ulik N. (2009), Osobowość typu D. Teoria i badania, Wydawnictwo WSHE, Łódź.

O g i ń s k a-B u l i k N., J u c z y ń s k i Z. (2007), Właściwości osobowości sprzyjajace chorobom somatycznym - rola typu $D$, „Psychoonkologia”, 11 (10).

O 1 e ś P. (2003), Wprowadzenie do psychologii osobowości, Scholar, Warszawa.

S e g a 1 H. (2005), Wprowadzenie do teorii Melanii Klein, GWP, Gdańsk.

$\mathrm{S}$ h a k e r P., R u b i n s te in C. (1980), Childhood attachment experience and adult loneliness, „Review of Personality and Social Psychology”, 1.

Sokolik M. (1988), Kliniczna problematyka poczucia tożsamości, Wydawnictwo UW, Warszawa.

Sokolik M. (1993), Psychoanaliza $i$ ja, Jacek Santorski \& CO Agencja Wydawnicza, Warszawa.

T e mos ho k L. (1987), Personality coping style, emotion and cancer: toward an integrative model, „Cancer Survey”, 6.

T u cholska S. (1997), Allporta koncepcja selfu, [w:] P. O léś (red.), Wybrane zagadnienia z psychologii osobowości, Wydawnictwo KUL, Lublin.

Z a k r z ew ska T. (1989), Psychospołeczne czynniki ryzyka zachorowania na raka, „Przegląd Psychologiczny", 4.

Z a l e w s k a M. (2003), Między życiem a śmierciq-problem psychicznej i fizycznej separacji od rodzica, „Nowiny Psychologiczne”, 1. 
Dorota Kubacka-Jasiecka

\section{Type C behavior pattern. Study of developmental and psychosocial factors and counterparts of WZC}

Type C personality - type C pattern - was introduced by T. Morris and S. Greer to define cancer personality, that is cancer-prone risk factor. It describes personality - behaviour pattern as negative emotionality: denial, non-expression of negative emotions (especially anger), helplessness, quietness, lack of self-assertion, pessimism, compliance. In time, researchers started to treat WZC as a risk factor of cancer and also other psychosomatic diseases (stomach ulcer, rheumatoid arthritis). WZC didn't gain such recognition and popularity like type A pattern. Precise analysis of a preliminary study shows interesting factors and counterparts, and describes its significance for psychosocial functioning and health. This study presents preliminary results of the research and influence on temperamental properties, early childhood experiences and later experiences of one's body, sense of value, gender, style of attachment, aggression, self-aggression and defensive capability for WZC development.

Keywords: type $\mathrm{C}$ behavior pattern, maternal bonding, body experience, neuroticism, development (wzór zachowania C, więź z matką, doświadczanie ciała, neurotyzm, rozwój). 